\title{
THE FOUR SEASONS OF THE MEXICAN RITUAL OF INFANCY
}

\author{
BY STANSBURY HAGAR
}

\begin{abstract}
$\Lambda^{P A P}$ PAPER by Doctor Seler ${ }^{1}$ called the writer's attention to a series of remarkable representations which occur in the codices Borgiano, Vaticanus 3773, and Fejervary-Mayer. ${ }^{2}$ Four groups of cleities are represented, each group in the performance of a different act, and all of these acts Seler rightly regards as symbolic representations of sacerdotal functions. ${ }^{3}$ In the Vaticanus and Borgiano codices there are five deities in each row, making twenty in all, while in the Fejervary there are eighteen deities very
\end{abstract}
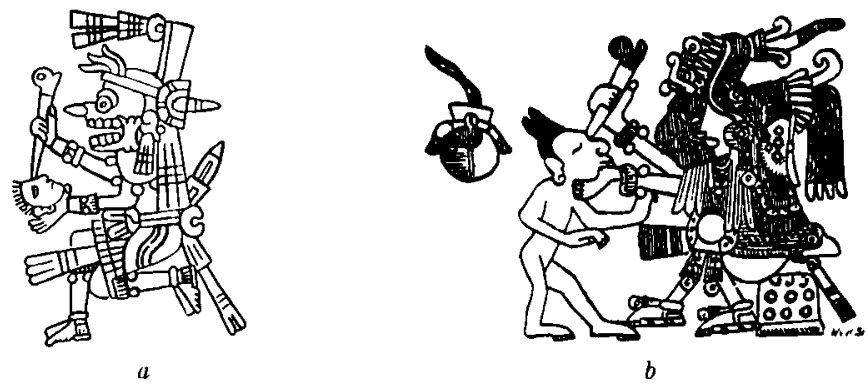

FIG. 40.

irregularly distributed amongst these groups. The sequence is the same in the Fejervary but differs in the Borgiano. The significance of these figures is fully revealed by comparing them with the descriptions of the ritual of the Mexican twenty-day periods given by Duran in his Historia de las Indias de Nueva España.

"In the first row," writes Seler, "the gods are each represented as boring out, with a pointed bone, the eye of a naked human figure standing before them" "(fig. 40). In the Vaticanus a severed head

1 Venus Period in Picture Writings, Bulletin 28 of the Bureait of A merican Ethnology, p. 355 et seq.

${ }^{2}$ Loubat edition, pp. I $5-17,33^{-42}, 23-28$, respectively.

s Op. cit. p. 367.

4 Ibid. 
takes the place of the human figure. These victims are females and the idea is evidently that of sacrifice. During the thirteenth month Duran describes the slaying of two young sisters, who represent famine and plenty. Moreover the sign Sagittarius governing this month was preëminently the sign of human sacrifice in Mexico. The principal sacrifice of the year took place under it.

In the second row of figures the gods are holding up in one hand an infantile representation of themselves (figs. $4 \mathrm{I}$ and 42 ). This seems

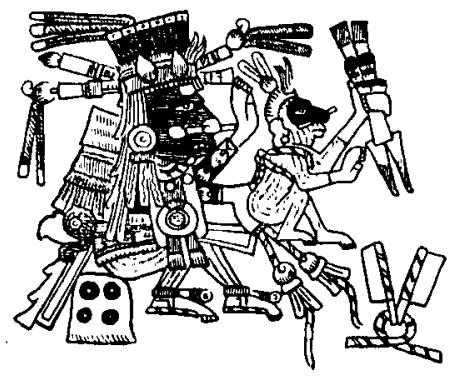

$a$

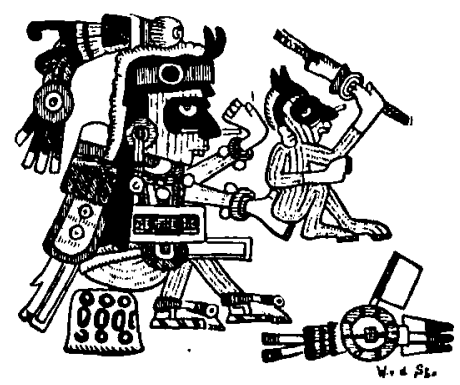

$b$

FIC. 4 I.

to refer to the rites of the Izcaalana or stretching out of infants begun during the eighteenth month under our sign Pisces. Parents stretched out the limbs of their children in the belief that unless this were done the children would not grow during the coming year.

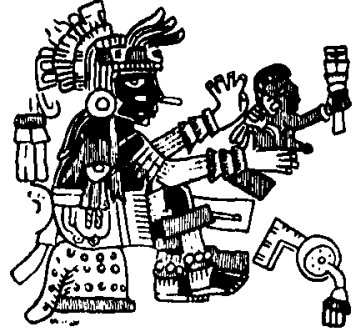

$a$

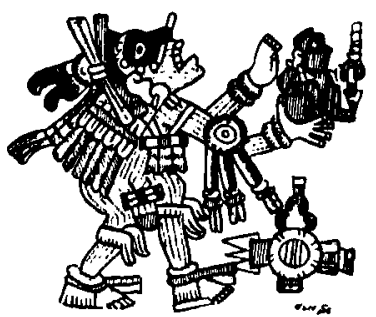

b

FIG. 42 .

Then each mother took hold of her child by the hair of its head and, lifting him upwards, addressed him frequently with the words 
"Ytzcalli, ytzcalli," meaning "Hail, hail," according to the commentator on the Codex Telleriano Ramensis. ${ }^{1}$ In reality these words probably placed the infant in the care of the gods with the declaration that its limbs had been properly stretched in the usual manner and it was therefore entitled to their protection for the ensuing year. This explains the gesture of giving mentioned by Seler in connection with this second row of deities. Nearly all the deities and infants in this row wear the black facial mask which characterizes the deities of the winter or night season of the year including the signs Sagittarius, Capricornus, Aquarius, and Pisces.
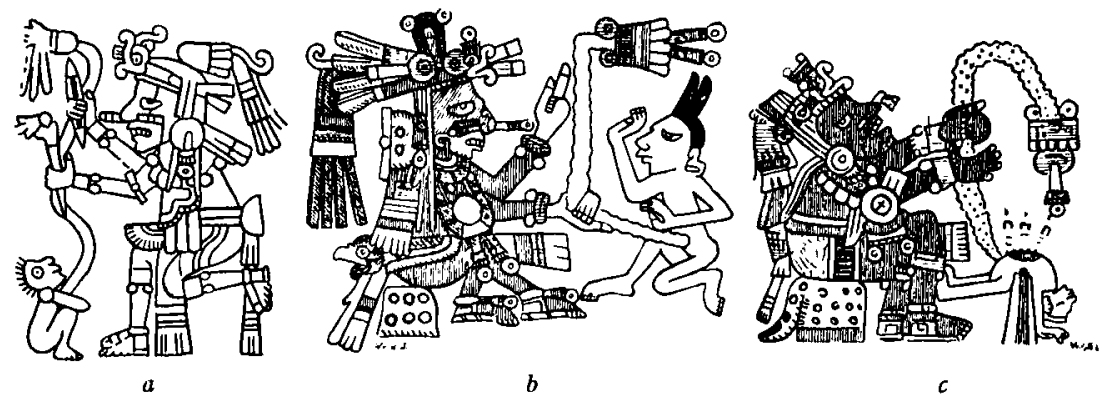

FIG. 43 .

In the third row the gods hold a tecpatl or flint knife, with which they are cutting or are about to cut the flesh-colored navel-cord of a new-born infant which terminates in flowers and precious stones. As it was customary for parents to call their offspring "my jewel," these latter symbols evidently pertain to the child (fig. 43). In a previous paper ${ }^{2}$ the writer has presented evidence that the twenty Mexican day signs govern portions of the zodiac in sequence and in this sequence the sign Tecpatl pertains to the region of our constellation Gemini. Under this sign in the fourth Mexican month Duran describes the rites of the Hueytozoztli as a purification of women who had given birth to children during the past year and as a circumcision of the infants, referring, no doubt, to a ceremonial cutting of their navel-cords.

1 Cf. Borgiano Codex, p. 52.

${ }^{2}$ Zodiacal Elements of the Mexican and Maya Months and Day Signs, Int. Cong. of Americanists. Mexico, I9Io. 
In the fourth row five female divinities offer the breast to as many naked infants. To the left in the Borgiano appears the symbol of the emerald and of the emerald water typifying the Tianquiztli or Market-place asterism, our Virgo, and the female sex (fig 44). Probably the emerald or jewel water refers also to a

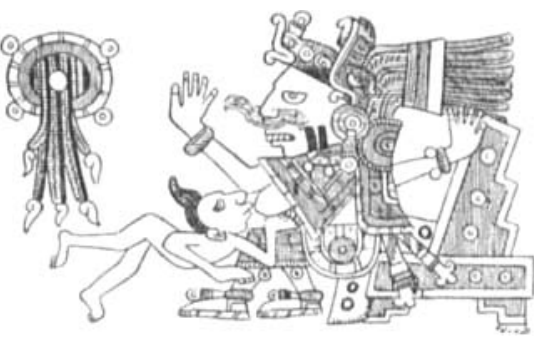

FIG. 44. woman's milk. Under Virgo in the eighth Mexican month Duran describes a ceremony and sacrifice of the midwives and female physicians. This is the female sign of the Mexican zodiac. It is governed by the asterism of the female symbol and by the various forms of the mother goddess, and its ritual pertains exclusively to women and their occupations. We may therefore conclude that the fourth row of divinities symbolizes the female ritual of Virgo.

This completes our study of the four rows of deities and we find them all associated with a ritual pertaining to childhood or infancy performed under our signs Sagittarius, Pisces, Gemini, and Virgo, on dates approximately equidistant. The ritual therefore represents the four seasons. Gemini governed the month of birth, i. e., the time when the birth ceremony was performed upon all infants born during the preceding year. Virgo similarly governed the month of motherhood and nursing. Sagittarius governed the month of sacrifice, and the symbolism leads us to suspect that the ritual may have referred to a sacrifice of children to ensure the safety of the other children born during the year. Finally Pisces governed the month of fruition or completion when the parents presented to the gods for their care and protection the finished reproduction of themselves.

Here the cycle of infancy ended contemporaneously with the end of the annual solar cycle. It is also worthy of notice that the four day-signs, Tecpatl, Calli, Tochtli, and Acatl, which mark the initial years of the great cycle of fifty-two years seem also to have governed the four seasons of infancy. In the Borgiano codex the 
figures of these seasons are accompanied by all the day signs in sequence but in the Fejervary and Vaticanus by the five day-signs Olin, Cipactli, Couatl, Atl, and Acatl. The last four represent four seasons but one month later than the seasons of our ritual.

We may also compare with these figures the four Bacab rulers of the Maya festivals in honor of the four seasons held during the supplementary days. In this ritual as given by Landa Sagittarius was represented by Canzicnal, the Serpent Being, Pisces by Zaczini, the White Being, Gemini by Hozanek, the Disembowelled asterism, and Virgo by Hobnil, the Hollow One. In the Sagittarius ritual young boys were cut with knives; under Gemini presents were made to the deity.

That there was an intentional comparison of the annual with the infants' cycle can hardly be doubted. No student of zodiacal mythology and symbolism can fail to recognize the general and very natural comparison of the annual journey of the sun with the spiritual journey of the human soul through life, a concept which forms a very important basic element of judicial astrology if not its principal one. In Mexico the prevalence and importance of astrology are well known. The aspect of the heavens was carefully noted at the moment of the birth of an infant and his future was foretold by means of the comparative position of the various asterisms at the time. But this was an individual matter and there seems to have been a purpose of bringing the individual into harmony with the divine cycle of celestial revolution by celebrating his birth under the sign governing universal birth, his nourishment under the sign governing universal nourishment, and so on. Thus the cycle of childhood became a miniature, so to speak, of the cosmic cycle, a note in its harmony.

But this symbolism was not entirely unrelated to physical conditions. A phallic ritual held under our sign Virgo in Mexico must have tended to produce a greater than average number of births under Gemini, the birth month. It is easy to account for this human mating season, which is found also in Peru and elsewhere, as occurring in the period of rest after the completion of the labors of the harvest, but it seems rather to have been originally 
a component part of the ceremonies preceding and during the harvest.

The ritual of the four seasons of infancy serves to emphasize farther how completely the Mexican ritual as a whole was associated with astronomic and astrologic relations. It indicates the necessity of understanding these relations in order to master the nature of Mexican religion and the significance of its symbolism.

BrookLyn Institute of ARTs and Sciences,

BrookLYN, N. Y. 